\title{
Toplum Beslenmesinde Sürdürülebilirlik ve Çevre
}

\author{
Sustainability in Public Nutrition and Environment
}

Gülsena Akay ${ }^{1}$,

Lütfi Saltuk Demir²,

${ }^{1}$ Necmettin Erbakan Üniversitesi, Sağlık Bilimleri Enstitüsü, Halk Sağlığı Anabilim Dalı, Konya, Türkiye

${ }^{2}$ Necmettin Erbakan Üniversitesi, Meram Tıp Fakültesi, Halk Sağlığı Anabilim Dalı, Konya, Türkiye

Geliş Tarihi/Received: 26 Mart 2019 Kabul Tarihi/Accepted: 19 Haziran 2019

Yazışma Adresi: Gülsena Akay, Necmettin Erbakan Üniversitesi, Sağlık Bilimleri Türkiye

e-mail: gulsenaakay@hotmail.com

\section{ORCID}

Gülsena Akay

https://orcid.org/0000-0002-5439-9550

Lütfi Saltuk Demir

https://orcid.org/0000-0002-8022-3962

\begin{abstract}
Öz
Sürdürülebilirlik, gelecek kuşakların intiyaç duyacağı kaynakların varlığını ve kalitesini koruyarak mevcut nesillerin intiyaçlarının karşılanmasıdır. Sürdürülebilir bir beslenme sistemi, şimdiki ve gelecek nesillerde sağlıklı bir yaşam için besin ve beslenme güvencesine katkıda bulunan düşük çevresel etkilere sahip bir diyeti ifade eder. Artan küresel nüfus, gelişen teknoloji, kentleşme ve sanayileşme sonucu beslenme sistemleri değişmiştir. Bu durum başta artan kronik hastalık insidansı olmak üzere pek çok sağlık sorununa ek olarak sera gazı salınımlarının artışı, su kaynaklarının ve arazilerin tahripleri gibi çevresel sorunlarla sonuçlanmaktadır. Cevresel değişimler ile beslenme sistemleri birbirleriyle ilişkilidir. Hayvansal besinleri yeterli miktarda içeren, bitkisel besin temelli olan bir beslenme modeli sağlık ve çevrenin sürdürülebilirliğini destekleyebilir.
\end{abstract}

Anahtar Kelimeler: Diyet, besin ve beslenme, çevre, sera gazı etkisi, su ayak izi

\section{Abstract}

Sustainability is satisfying the needs of present generation by pro tecting presence and quality of resources that future generations will need. A sustainable nutrition system refers to a diet with low environmental impacts which contribute to food and nutrition security for healthy life for present and future generations. Nutrition systems has changed as a result of growing global population, developing the technology, urbanization and industrialization. This situation result in environmental problems as water resources and land uses and increasing greenhouse gases emissions in addition to several health problems notably increasing cronic diseases incidence. Environmental changes and nutrition systems are interrelated. A nutrition model which is containing animal based food enough and plant based can supply sustainability of health and environment.

Key words: Diet, food and nutrition, environment, greenhouse gas effect, water footprint
Atıf yapmak için: Akay G, Demir LS. Toplum Beslenmesinde Sürdürülebilirlik ve Çevre. Selcuk Med J 2020;36(3): 282-287
Açıklama: Yazarların hiçbiri, bu makalede bahsedilen herhangi bir ürün, aygıt veya ilaç ile ilgili maddi çıkar ilişkisine sahip değildir. Araştırma, herhangi bir dış organizasyon tarafından desteklenmedi. Yazarlar çalışmanın birincil verilerine tam erişim izni vermek ve derginin talep ettiği takdirde verileri incelemesine izin vermeyi kabul etmektedirler. 


\section{GíRiş}

Sağlığın korunmasında ve hastalıkların önlenmesinde yeterli ve dengeli beslenme temeldir. Beslenme, sağlığı korumak ve yaşam kalitesini yükseltmek için vücudun gereksinimi olan besin ögelerini yeterli miktarlarda ve uygun zamanlarda almak için bilinçli yapılması gereken bir eylemdir. $\mathrm{Bu}$ eylem yaşam döngüsünün her aşamasında sağlanmalıdır (1). Bugün dünya, özellikle de gelişmekte olan ülkeler, malnütrisyonun yetersiz beslenme ve kilolu olmayı içeren her iki yüküyle karşı karşıyadır (2). Dünya Sağlık Örgütü Küresel Beslenme Raporu 2017 verilerine göre, dünya genelinde 2 milyar yetişkin aşırı kilolu veya obez, 41 milyon çocuk fazla kilolu, 115 milyon çocuk bodur, 52 milyon çocuk zayıftır. Gizli açlık ya da vitamin ve mineral eksiklikleri, yaklaşık olarak 2 milyar insanı etkilemektedir (3). Dünya üzerinde tarımla yaklaşık 12 ila 14 milyar insan için yeterli besin üretilebilecek kapasite bulunmaktayken, 850 milyon ya da dünya nüfusunun sekizde biri, kronik açlık çekmektedir (4).

İnsanların yeterli gıda tüketmesini engelleyen faktörler; gıdanın bulunabilirliği, ulaşılabilirliği ile tedarik kararlılığı ve gıdanın yenilebilirliği olarak tanımlanmaktadır (5). Beşeri faktörler ve doğal kaynaklar, besinlerin ve beslenme sisteminin temelini oluşturur fakat teknoloji, politikalar, ekonomi, eğitim, sosyokültürel eğilimler ve araştırmalar da beslenme sisteminin işleyiş biçimini etkilemektedir (6). Sürdürülebilirlik ve sürdürülebilir kalkınma terimleri ilk olarak 1983'te Brundtland Komisyonu tarafından ele alınmıştır. Brundtland Komisyonu, sürdürülebilir kalkınmayı; 'gelecek nesillerin kendi ihtiyaçlarını karşılayabilme yeteneklerinden ödün verilmeden mevcut nesillerin ihtiyaçlarının karşılanması' olarak tanımlamıştır (7). Daha sonra, 1986 yılında, sağlıklı tüketicilerin yanı sıra daha sağlıklı ortamlarla sonuçlanacak diyet önerileri ile 'sürdürülebilir diyet' kavramı önerilmiştir (8).

Toplum beslenmesi faaliyetlerinde sürdürülebilirlik, halkın beslenme intiyaçlarını temel olarak biyolojik sağlık bağlamında çerçevelediği için büyük ölçüde göz ardı edilmiştir. Fakat fiziksel sınırların olduğu bir dünyada yaşadığımız değişmez bir gerçektir (9). Sağlık ve beslenme profesyonelleri, mevcut beslenme sistemimizi ve sistemin çevresel, sosyal ve sağlık etkilerini bir bütün olarak ele almalıdırlar. Çünkü popülasyonlara yönelik sağlık riskleri; fiziksel çevreden, kültürel çevreden ve insanların buradaki varlıklar ile sistemler üzerindeki etkisinden doğmaktadır (6). Yetişmiş eğitimciler olarak diyetisyenler, sürdürülebilir beslenme sistemi ilkelerinin ve diyetlerinin desteklenmesinde önemli bir yere sahiptir (10). Bu derlemede, sürdürülebilirlik kavramının toplum beslenmesindeki yeri hakkında literatür doğrultusunda bilgi sağlamak amaçlanmıştır.

\section{Sürdürülebilir Beslenme}

Sürdürülebilirlik; daimi olma, yarına kalabilme ve varlığını devam ettirebilme yeteneği olarak ifade edilebilir (7). Gıda ve Tarım Örgütü (FAO), 2010 yılında sürdürülebilir beslenmeyi; 'Sürdürülebilir diyetler, şimdiki ve gelecek nesillerde sağlıklı bir yaşam için ve besin ve beslenme güvencesine katkıda bulunan düşük çevresel etkilere sahip diyetlerdir. Sürdürülebilir diyetler, biyolojik çeşitliliğe ve ekosisteme karşı koruyucu ve saygılı, kültürel olarak kabul edilebilir, ulaşılabilir, ekonomik açıdan uygun ve satın alınılabilir; beslenme açısından yeterli, güvenli ve sağlıklı; doğal ve insan kaynaklarını en iyi şekilde kullanan diyetlerdir.' şeklinde tanımlamıştır (11). Toplum sağlığı beslenmesinde sürdürülebilirlik, mevcut ve gelecekteki nüfusların sağlıklı beslenme intiyaçlarını desteklemek için besin üreten ekolojik sistemleri koruyarak besin sistemi kapasitesini muhafaza etme yeteneğini ifade etmektedir (9). Sürdürülebilir bir diyetin 6 temel bileşeni bulunmaktadır (Tablo 1).

Sürdürülebilirliği tanımlamanın karmaşıklığının yanında mevcut diyetlerin sürdürülemez olduğuna dair kanıtlar artmaktadır (12). Küresel diyet kalıpları son 50 yılda çarpıcı bir şekilde değişmiş, bu değişim toplumların sağlığı için bir tehdit oluşturmuştur (13). Sağlıklı ve sürdürülebilir bir diyet; yoğun enerji içeren,

Table 1. Sürdürülebilir bir diyetin temel bileşenleri

\author{
Sürdürülebilir Diyetler \\ İilik hali, sağlık \\ Biyoçeşitlilik, çevre, iklim \\ Eşitlik, adil ticaret \\ Çevre dostu, yerel, mevsiminde besinler \\ Kültürel miras, beceriler \\ Besin ve besin ögesi ihtiyaçları, besin güvenliği, erişilebilirlik
}


yüksek oranda işlenmiş ve paketlenmiş gıdaların tüketimini en aza indirir, daha az hayvansal besin, daha fazla bitkisel kaynaklı besin içerir ve insanları önerilen günlük enerji alımını geçmemeye teşvik eder. Sürdürülebilir diyetler, besin ve beslenme güvenliğine katkıda bulunur, düşük çevresel etkilere sahiptir, mevcut ve gelecek nesiller için sağlıklı yaşamı teşvik eder (14). Sürdürülebilir diyetler, düşük çevresel etki, ekonomik istikrarlı ve uygun fiyatlı, erişilebilir besinler ile halk sağlığını destekler (13).

Diyetler, çevre ve insan sağlığı ile ilişkilidir (15). Küresel çevresel değişimler ile besin sistemleri arasındaki ilişki çift yönlüdür. Besin sistemlerinin işleyişleri, besinlerin güvenliği, verimliliği ve kalitesi yönünden çevresel değişimlerden etkilenebildiği gibi çevresel değişimlere katkıda bulunan en önemli faktörlerden birisi de besin sistemlerinin süreçleri ve çıktılarıdır (16).

\section{Sera Gazı Emisyonu}

İklim değişikliğinin bir sonucu olan küresel ısınmanın insan sağlığı için büyük etkileri olabileceği tahmin edilmektedir. Küresel sera gazı emisyonlarının yaklaşıkolarak \%30'ununtarımdanve bunabağlıolarak da arazi kullanım değişikliklerinden kaynaklandığı tahmin edilmektedir (17). Yaşam döngüsü analizi (LCA), bir ürünün yaşam döngüsü boyunca veya bir aşamasında ekolojik yükünü değerlendirmek için kullanılabilecek bir göstergedir (18). Besin üretiminin işleme, depolama, taşınma, dağıtım ve atıkların da dahil olduğu 'yaşam döngüsünün' her adımının çevre üzerinde etkileri vardır. (19). Bu fonksiyonel birime göre, hayvansal kaynaklı gıdalar, özellikle de ruminant et, bitkisel gıdaların üretiminden daha fazla sera gazı yaymaktadır (20). Besin üretimi, muhafazası ve dağıtımı, toplam karbondioksit emisyonuna katkıda bulunan önemli miktarda enerji tüketir (18). Macdıarmıd et al. (21) çalışmasına göre, İngiltere'de üretilen farklı besin gruplarındaki besinlerin sera gazı etkileri yüksek, orta ve düşük etkili olarak Tablo 2 . de gösterilmiştir. Tabloya göre, hayvansal kaynaklı besinlerin bitkisel kaynaklı besinlere göre sera gazı emisyonu etkisinin daha yüksek olduğu görülmektedir. Daha korunmuş koşullarda yetiştirilen hassas meyve ve sebzelerin ise diğer bitkisel kaynaklı besinlere göre daha yüksek sera gazı emisyonu etkisi olduğu görülmektedir.

Bazı ülkeler, sera gazı emisyonlarını azaltmak ve çevresel etkilerin sınırlandırılması için sürdürülebilir diyet tavsiyelerinde bulunan diyet rehberleri geliştirmiştir. Katar, Brezilya, İsveç ve Hollanda gibi birçok ülke, ulusal diyet tavsiyelerinde sürdürülebilirliği desteklemektedir. Hazırladıkları diyet rehberlerinde et tüketimini sınırlandıran ve sürdürülebilir şekilde üretilen balık tüketimini artıran önerilere dikkat çekilmektedir $(12,22)$.

\section{Su Ayak İzi}

Bir mal veya hizmet üretmek için gerekli tatlı su miktarının tüm tedarik zinciri içindeki ölçümünü ifade eden su ayak izi; hammaddenin işlenmesinden, doğrudan operasyonlara ve tüketicinin ürünü kullanmasına kadar geçen tüm süreci kapsar. Böylece, su ayak izi kavramı hem doğrudan su kullanımını hem de üretim sürecindeki dolaylı su kullanımını hesaba katar (23). Tarımsal üretim, bu toplam ayak

Table 2. Ingiltere'de üretilen farklı besin gruplarındaki besinlerin sera gazı etkileri

\begin{tabular}{|c|c|c|}
\hline $\begin{array}{l}\text { Düşük GHGE } \\
\text { ( }<1.0 \mathrm{~kg} \mathrm{CO} e / \mathrm{kg} \\
\text { yenilebilir ağırlık) }\end{array}$ & $\begin{array}{l}\text { Orta GHGE } \\
(1.0-4.0 \mathrm{~kg} \mathrm{CO} e / k g \\
\text { yenilebilir ağırlık) }\end{array}$ & $\begin{array}{l}\text { Yüksek GHGE } \\
\text { (>4.0 kg CO } \mathrm{CO}_{2} / \mathrm{kg} \\
\text { yenilebilir ağırlık) }\end{array}$ \\
\hline Patates & Tavuk & Sığır eti \\
\hline Makarna, erişte & Süt, tereyağı, yoğurt & Kuzu \\
\hline Ekmek & Yumurta & Domuz \\
\hline Yulaf & Pirinç & Hindi \\
\hline $\begin{array}{l}\text { Sebzeler (soğan, bezelye, } \\
\text { havuç, tatlı mısır, brassica) }\end{array}$ & Kahvaltılık gevrek & $\begin{array}{l}\text { Balık } \\
\text { Peynir }\end{array}$ \\
\hline $\begin{array}{l}\text { Meyveler (örneğin elma, } \\
\text { armut, narenciye, erik, üzüm) }\end{array}$ & Ekmek üstüne sürülen soslar(spreads) & \\
\hline Fasulye, mercimek & Findık, tohumlar & \\
\hline Şekerleme, şeker & Bisküvi, kek ve tatlılar & \\
\hline Lezzetli atıştırmalıklar & $\begin{array}{l}\text { Meyveler (örneğin, çilek, muz, kavun) } \\
\text { Salata sebzeleri } \\
\text { Sebzeler (örneğin, mantar, yeşil fasulye, } \\
\text { karnabahar, brokoli, kabak) }\end{array}$ & \\
\hline
\end{tabular}


izine \% 92 oranında katkıda bulunmaktadır (24). Dünyada tarımın toplam su ayak izinin yaklaşık üçte biri hayvansal ürünlerin üretimi ile ilgilidir. Herhangi bir hayvansal ürününün su ayak izi, eşdeğer besin değeri olan bitkisel ürünlerinin su ayak izinden daha büyüktür. Mekonnen ve Hoekstra' nın yaptıkları çalışmada sığır eti için kalori başına ortalama su ayak izinin, tahıllar ve nişastalı bitkilere göre 20 kat daha büyük olduğu; süt, yumurta ve tavuk eti için protein gramı başına düşen su izinin, bakliyatlara göre 1,5 kat daha büyük olduğu bildirilmiştir (25).

\section{Beslenme Modelleri ve Sürdürülebilirlik}

Sürdürülebilir besin sistemleri çerçevesinde hem açlık hem de büyüyen obezite durumuyla aktif olarak mücadele etmek için yeni beslenme davranışları geliştirilmeli, önerilmeli ve yayılmalıdır. Bu kapsamda, Akdeniz diyeti sürdürülebilir diyetin çok etkili bir modelini temsil etmektedir. Akdeniz diyeti; diyetin besin kalitesini sağlayan biyoçeşitliliğin olması, çeşitli besin hazırlama ve uygulama tekniklerinin bulunması, sağlığa yararlı olduğu bilinen zeytinyağı, balık, meyve ve sebze, bakliyat, fermente sütün bulunması, kültür ve geleneklere güçlü bir bağlılığı olması, insan doğasına ve mevsimselliğe saygılı olması, hayvansal ürünlerin az tüketilmesi nedeniyle çevresel etkilerinin az olmasından ötürü kısmen sürdürülebilir olarak düşünülmektedir (11). 2009 yılında geliştirilen "Çift Piramit Beslenme Modeli", besin üretiminin ve tüketiminin neden olduğu çevresel etkiler ile onların besinsel içerikleriyle yakın ilişkilidir. Beslenme uzmanlarının tavsiye ettikleri Akdeniz tipi beslenme gibi ekonomiyi olumsuz olarak etkilemeden çevresel olarak sürdürülebilir bir beslenmenin uygulanması mümkündür. Çift Piramit Modeli, klasik besin piramidinin (Akdeniz beslenmesinin) yanına besinlerin ekolojik ayak izlerinin sınıflandırılarak yeni ters çevrilmiş çevresel piramidin yerleştirildiği bir diyagramdır (26).

Vejetaryen diyetlerin dikkatli planlandığında sağlık üzerinde olumlu etkilerinin olduğu görülmüştür (27). Vejetaryen yemek ve diyetlerin omnivorlara göre daha az çevresel etkiye sahip olduğu gösterilmektedir (28). Organik besin üretimi, küresel besin arzına önemli ölçüde katkıda bulunma ve geleneksel tarımın çevresel etkilerini azaltma potansiyeline sahip olarak görülmektedir (11). Organik tarım, dış girdilere daha az bağımlı olduğu ve doğal kaynakları korumada daha güçlü bir yeteneğe sahip olması sebebiyle geleneksel tarıma göre avantajlıdır (19). Yerel beslenme hareketi, üretim ve tüketim alanı arasındaki en kısa mesafeyi ifade etmektedir (29).
1990 yılında geliştirilen 'gıda mili' terimi besinlerin çiftlikten tabağa kadar olan yolculuğunu tanımlarken, yerel olarak yetiştirilen ve üretilen besinlerin uzak mesafelere gitmesi gereken besinlere göre daha çevre dostu olduğunu belirtmektedir (14). İnsanlık tarihi boyunca yaklaşık 30000 yenilebilir bitki türünden 6000-7000 tür beslenme için yetiştirilmektedir. Ancak günümüzde sadece ticari olarak önemli bir ölçekte yaklaşık 170 ürün yetişilmektedir. Küçük bir coğrafyada yetişmeleri, düşük verime sahip olmaları, yoğun işlem gerektirmeleri, zararlılara karşı hassas olmaları gibi nedenlerden dolayı ihmal edilen binlerce ürün vardır. İhmal edilen ürünler genellikle yerel veya geleneksel besinlerdir. Bu besinler; besin öğesi içerikleri ile diyetleri zenginleştirmeleri, sürdürülebilir tarımı desteklemeleri, iklim değişikliğine karşı dirençli olmaları, geleneksel bilgiyi canlı tutmaları, küçük ölçekli çiftçilerin ve yerel üreticilerin geçimlerini sağlamaları ile önemli faydalar sunmaktadır (30). Son yıllarda şekillenen, duyarlılıkları çerçevesinde harekete geçen yeni üreticilerin ve yeni tüketicilerin hayatında, yerel olmayan ürünlerin, gelmesi için kilometrelerce yol kat etmesi ve bunun sonucunda çevreye verdiği geri dönülemez zararlar, değiştirilmesi gereken kaygı duyulan konular haline dönüşmüştür (29).

"Gezegensel Sağlık Diyeti”, EAT-Lancet Komisyonu tarafından diyetlerin insan sağlığı ve çevresel sürdürülebilirlik açısından kritik rolünü vurgulamak için geliştirilmiştir. Bu beslenme modelinde, tabağın yarısında sebze ve meyvelerin bulunması, enerji desteği olarak tam tahılların tüketimi, bitkisel protein kaynakların tüketimi, doymamış bitkisel yağların tüketimi ve sınırlı miktarda hayvansal protein kaynaklarının tüketimi önerilmektedir. Bu diyetle, 10 milyar nüfusu doyurmak, her yıl 11 milyon insanın açlık ve yanlış beslenme kaynaklı hastalıklardan ölmesini engellemek, sera gazı salınımlarını en aza indirgemek, herhangi bir türün yok olmasını engellemek, su ve diğer doğal kaynakları korumak hedeflenmektedir (31). 2013 yılında Hollanda' da Van Dooren et al. (32) tarafından yapılan çalışma sonucunda, Akdeniz diyetinin sağlık skorunun diğer tüm diyetlerden daha yüksek olduğu, sürdürülebilirlik skorunda (sera gazı salınımı endeksine göre) semi-vejetaryen diyet, geleneksel vejetaryen diyet, vegan diyet ve Akdeniz diyetinin ideal aralıkta olduğu fakat vegan diyetin diğer tüm diyetlerden daha yüksek sürdürülebilirlik skoruna sahip olduğu belirtilmiştir. 2013 yılında İngiltere' de Scarborough et al. tarafından yapılan bir çalışmada, İngiltere'de et tüketenler, balık tüketenler, vejetaryen 
ve veganlar arasındaki sera gazı emisyonları farkına bakılmıştır. Cinsiyet ve yaşa göre eşitlenen gruplarda günlük sera gazı emisyonunun kilogram cinsinden karbondioksit miktarları incelendiğinde, yüksek miktar et tüketenlerin en fazla ortalamaya sahip olduğu görülmüştür. Yüksek miktar et tüketenlerden sonra sırayla orta düzeyde et tüketenler, düşük düzeyde et tüketenler, balık tüketenler, vejetaryenler ve veganlar gelmiştir. Çalışmanın sonucunda et tüketenlerin sera gazı emisyon değerleri veganların yaklaşık iki katı olarak bulunmuştur (33). Önemli sağlık faydaları sunan alternatif diyetler yaygın olarak benimsenirse, küresel tarımsal sera gazı emisyonlarının ve arazi tahriplerinin azaltılmasına, bunun sonucunda yok olan türlerin engellenmesine ve diyetle ilişkili bulaşıcı olmayan kronik hastalıkların önlenmesine yardımcı olabilir (15).

Sonuç olarak, sürdürülebilirlik terimi yaşadığımız çevrenin sınırlı kaynakların daha verimli kullanılabilmesi ve gelecek nesillere daha iyi bir dünya bırakılabilmesinin merkezinde yer almaktadır. Toplumların sağlıklı bir yaşam sürmesinde beslenme ve çevre ilişkisi önemlidir. Hem yetersiz beslenme hem de aşırı beslenme ile mücadele etmek, besin güvenliğini sağlamak, atıkları azaltmak, çevresel etkileri en aza indirmek için kültürel olarak kabul edilebilir, ulaşılabilir, ekonomik olarak uygun sürdürülebilir beslenme sistemleri geliştirilmeli ve önerilmelidir.

Çıkar Çatışması: Çalışmada herhangi bir çıkar çatışması yoktur.

Finansal Çıkar Çatışması: Çalışmada herhangi bir finansal çıkar çatışması yoktur.

Address correspondence to: Gülsena Akay, Necmettin Erbakan Üniversitesi, Sağlık Bilimleri Enstitüsü, Halk Sağlığı Anabilim Dalı, Konya, Türkiye

Telefon: 05423130027

e-mail: gulsenaakay@hotmail.com

\section{KAYNAKLAR}

1. Hacettepe Üniversitesi Beslenme ve Diyetetik Bölümü: Türkiye'ye Özgü Besin ve Beslenme Rehberi TOBR, Ankara, 2015.

2. World Health Organization Nutrition, Challenges. Available from: http://www.who.int/nutrition/challenges/en/ [Last accessed 27 September 2018]

3. World Health Organization Global Nutrition Report. Available from: http://www.who.int/nutrition/globalnutritionreport/en/ [Last accessed 27 September 2018]

4. Food and Agriculture Organization of the United Nations (FAO). Building a common vision for sustainable food and agriculture. Rome, 2014. Available from: http://www.fao. org/3/a-i3940e.pdf [Last accessed 06 October 2018]

5. Brüntrup M. Global trends in food security. Rural 2008;42(3): 8-11.

6. O'Kane G. What is the real cost of our food? Implications for the environment, society and public health nutrition. Public Health Nutr 2012; 15(2): 268-76.

7. World Commission on Environment and Development. Ourcommonfuture. Oxford: Oxford University Press, 1987.

8. Gussow JD, Clancy K. Dietary guidelines for sustainability. J Nutr Educ 1986;18:1-5.

9. Lawrence M, Burlingame B, Caraher M, et al. Public health nutrition and sustainability. Public Health Nutr 2015; 18(13): 2287-92.

10. Wegener J. Equipping future generations of registered dietitian nutritionists and public health nutritionists: A commentary on education and training needs to promote sustainable food systems and practices in the 21 st century. $J$ Acad Nutr Diet 2018;118(3): 393-8.

11. Food and Agriculture Organization of the United Nations (FAO). Burlingame B, Dernini S, editors. Sustainable diets and biodiversity: Directions and solutions for policy, research and action. Proceedings of the International Scientific Symposium on Biodiversity and Sustainable Diets. Rome 2012. Available from: http://www.fao.org/docrep/016/i3004e/ i3004e.pdf [Last accessed 12 October 2018]

12. Burlingame $B$, Dernini $S$. Sustainable diets: The Mediterranean diet as an example. Public Health Nutr 2011; $14(12 \mathrm{~A}): 2285-7$.

13. Johnston, JL, Fanzo, JC, Cogill, B. Understanding sustainable diets: A descriptive analysis of the determinants and processes that influence diets and their impact on health, food security, and environmental sustainability. Adv Nutr 2014; 5(4):418-29.

14. Alsaffar AA. Sustainable diets: The interaction between food industry, nutrition, health and the environment. Food Sci Technol Int 2016;22(2):102-11.

15. Tilman D, Clark M. Global diets link environmental sustainability and human health. Nature 2014;515(7528): 518.

16. Allen T, Prosperi P. Modeling sustainable food systems. J Environ Manage 2016; 57(5): 956-75.

17. Briggs AD, Kehlbacher A, Tiffin R, et al. Simulating the impact on health of internalising the cost of carbon in food prices combined with a tax on sugar-sweetened beverages. BMC Public Health 2015; 16(1):107.

18. Roy $P$, Nei $D$, Orikasa $T$, et al. A review of life cycle assessment (LCA) on some food products. J Food Eng 2009; 90(1):1-10.

19. Food and Agriculture Organization of the United Nations (FAO). Assessing sustainable diets within the sustainability of food systems. Mediterranean diet, organic food: new challenges. Available from: http://www.fao.org/3/a-i4806e. pdf [Last accessed 10 October 2018]

20. Masset G, Vieux F, Darmon,N. Which functional unit to identify sustainable foods? Public Health Nutr 2015;18(13):2488-97.

21. Macdiarmid JI, Kyle J, Horgan GW, et. al. Sustainable diets for the future: Can we contribute to reducing greenhouse gas emissions by eating a healthy diet? Am J Clin Nutr 2012;96(3):632-9.

22. Horgan GW, Perrin A, Whybrow S, et al. Achieving dietary recommendations and reducing greenhouse gas emissions: Modelling diets to minimise the change from current intakes. Int J Behav Nutr Phys Act 2016;13(1), 46. 
23. World Wildlife Fund (WWF) Türkiye'nin Su ayak izi raporu. 2014. Available from: http://www.wwf.org.tr/?2720 [Last accessed 24 October 2018]

24. Mekonnen MM, Hoekstra AY. National water footprint accounts: The green, blue and grey water footprint of production and consumption. In: Mekonnen MM, Hoekstra ed. Value of Water Research Report Series. Delft: UNESCOIHE Institute for Water Education 2011;25-6.

25. Mekonnen MM, Hoekstra AY. A global assessment of the water footprint of farm animal products. Ecosystems 2012;15(3):401-415.

26. Barilla Center. For food and nutrition. Double pyramid 2015. Recommendations for a sustainable diet. Available from: https://www.barillacfn.com/m/publications/dp-2015-en.pdf [Last accessed 11 October 2018]

27. Karabudak E. Vejetaryen beslenmesi. Ankara: Sağlık Bakanlığı Yayın 2008:9-10.

28. Vieux F, Soler LG, Touazi D. High nutritional quality is not associated with low greenhouse gas emissions in selfselected diets of French adults. Am J Clin Nutr, 2013; 97(3):569-583.

29. Kanık İ. Yerel beslenme hareketi ve bir kitle iletişim anlatısı dizaynı: Amerika Birleşik Devletleri (ABD) örneği (Local food movement and a narrative design for mass communication: The US case). İstanbul 2014; 2(4):14.

30. http://www.fao.org/fao-stories/article/en/c/1154584/ [Last accessed 24 October 2018]

31. Willett W, Rockström J, Loken B, et al. Food in the Anthropocene: The EAT-Lancet Commission on healthy diets from sustainable food systems. Lancet 2019;S01406736(18):31788-4.

32. Van Dooren C, Marinussen, M, Blonk $\mathrm{H}$, et al. Exploring dietary guidelines based on ecological and nutritional values: A comparison of six dietary patterns. Food Policy 2014;44: 36-46.

33. Scarborough P, Appleby PN, Mizdrak A, et al. Dietary greenhouse gas emissions of meat-eaters, fish-eaters, vegetarians and vegans in the UK. Clim Change 2014; 125(2):179-92. 